\title{
A Framework for Research and Practice: Relationship among Authentic Leadership, Employee Well-Being, Organizational Innovative Climate and Innovative Behavior
}

\author{
Peiyan Huang \\ School of Management, Jinan University, Guangzhou, China \\ Email: herrysam202@yahoo.com
}

How to cite this paper: Huang, P. Y. (2017). A Framework for Research and Practice: Relationship among Authentic Leadership, Employee Well-Being, Organizational Innovative Climate and Innovative Behavior. Open Journal of Leadership, 6, 126-134.

https://doi.org/10.4236/ojl.2017.63009

Received: August 24, 2017

Accepted: September 22, 2017

Published: September 27, 2017

Copyright $\odot 2017$ by author and Scientific Research Publishing Inc. This work is licensed under the Creative Commons Attribution International License (CC BY 4.0).

http://creativecommons.org/licenses/by/4.0/

\begin{abstract}
In this research, we propose to use literature research method to explore a new research model to explain the relationship between authentic leadership and innovative behavior. Research result shows that authentic leadership is positively related to innovative behavior via employee well-being. What's more, when organizational innovative climate is high, the relationship between employee well-being and innovative behavior would be strengthened, on the contrary, it is weakened. We believe that these findings are important for guiding future empirical research in employee's innovative behavior.
\end{abstract}

\section{Keywords}

Authentic Leadership, Innovative Behavior, Employee Well-Being, Organizational Innovative Climate, Innovation

\section{Introduction}

Innovation has become a hot topic in organizational science when the society is becoming increasingly competitive (Crossan \& Apaydin, 2010; Garud et al., 2013; Özarall1, 2015). As related research states, individuals contribute to overall team innovation, and innovative behavior of employees is an important source of innovation within the organization (Wegner, 1987; Fan et al., 2016). According to prior research, innovative behavior is positively related to employee's job productivity (Changa \& Liub, 2008); organizational performance (Yuan \& Woodman, 2010); and organizational success (Tewari, 2011) in a dynamic business environment. Therefore, scholars have increasingly recognized the impor- 
tance of individual innovative behavior and try to make further research on it.

Given the significance of innovative behavior, scholars have attempted to identify specific variables that predict innovative behavior. According to previous research, antecedents of innovative behavior can be generally divided into four categories: personal factors (e.g. personality traits, motivation), contextual influences (e.g. Justice, organizational support), job characteristics (e.g. task complexity), and the interaction between personal factor and contextual factor (Shalley et al., 2004; Hammond et al., 2011). Especially, innovation and leadership are closely related (Slimane, 2015). Leaders usually control job related resources and play a critical role in affecting employee's behavior (Zhang, Wang, \& Shi, 2012). Authentic leadership is a kind of emerging leadership which attracts wide attention during these years. In the study of authentic leadership, scholars believe that authentic leadership would affect employee's positive attitude and behavior (Avolio \& Gardne, 2005). Innovative behavior is one of positive behaviors for the enterprise, yet few studies discuss the relationship between authentic leadership and innovative behavior. Rego tried to explore the relationship between authentic leadership and employee's creativity in his study. Since then, scholars gradually focus the relationship between authentic leadership and innovation (Rego et al., 2014). However, definite correlation between authentic leadership and innovative behavior still remained to be explored. Thus, the primary aim of this study is to investigate whether authentic leadership is positively related to innovative behavior. It would not only contribute to extend current knowledge of the role of authentic leadership, but also provide guidance in innovative behavior at work.

Additionally, how authentic leadership influences employee's innovative behavior also remains a question. On the one hand, we find that the intermediate mechanism trying to explain authentic leadership and some related outcomes (creativity, innovation) is usually discussed from the single perspective, for example, from perspective of emotion (e.g. employee's affect, employee's emotion) or cognition (e.g. perception of support for innovation, basic need satisfaction), but studies rarely consider cognitive and emotional factors in the same time in mediation. On the other hand, current literature about authentic leadership also increasingly calls for considering different types of intermediary variable to explain the relationship between authentic leadership and some related outcomes (Özlem et al., 2016). In the process of reading the literature, we find that employee well-being (EWB) is a potential intermediary variable. Employee well-being not only involves employee's perception and feeling but also their psychological experience and the level of satisfaction (Zheng et al., 2015). In other words, employee well-being is the variable combined cognition and emotion together. In addition, prior research has shown that employee well-being is valuable in understanding innovative behavior (Sharifirad, 2013). However, there are few studies take employee well-being into account in the relationship between authentic leadership and innovative behavior. What's more, drawing on broaden-and-build theory (Fredrickson 1998), employees' positive psychology 
resources would broaden people's momentary thought-actions that come to mind, and also enable people to explore, take in new information and experiences, and expand the self in the process (Fredrickson, 1998; Ryan \& Deci, 2000). Therefore, the second aim of this study is to illustrate that employee well-being serves as an intermediate mechanism between authentic leadership and innovative behavior.

According to the existing researches, employee's behavior is affected not only by the individual psychology but also by the organizational climate (Shalley, et al., 2004; Hammond et al., 2011). And situational strength theory thinks that organizational settings have large impact on individual attitudes and behavior (Meyer, et al., 2010). In fact, employee well-being does not directly transform into employee's innovative behavior, support and encouragement from the organization is also essential. Furthermore, we have discovered that organizational innovative climate is one of vital variables predicting innovative behavior, and different extent of organizational innovative climate would lead to different extent of innovative behavior (Yu et al., 2013). Therefore, we tend to believe that organizational innovative climate is likely to moderate the relationship between employee well-being and innovative behavior.

Overall speaking, considering both contextual influence and employee's psychological process simultaneously, this investigation contributes to test the relationship between authentic leadership and innovative behavior. More specifically, we test the mediating role of employee well-being and the moderating effect of team climate in this model. Through comprehensive perspective of authentic leadership theory and broaden and build theory, this investigation would broaden our knowledge of innovative behavior and would help organizations to increase employee's innovative behavior better.

\section{Method}

In order to achieve the objection of the research, we could mainly use literature research method to do this study. Literature research is a useful method to do research by collecting and analyzing various existing literature. Literature research allows scholars to select the latest information and finally to achieve the purpose of research. Overall speaking, there are two obvious benefits by choosing this method. Firstly, we can know the latest trends in related studies, for example, new theory, new variables and new direction in the field of authentic leadership and innovative behavior. Secondly, through reviewing the literature, we can reintegrate the research model by considering the latest change and strong evidence in related research.

\section{Hypothesis Development}

\subsection{Authentic Leadership and Innovative Behavior}

Authentic leadership (AL) can be defined as a pattern of leader behavior that draws upon and promotes both positive psychological capacities and a positive 
ethical climate, to foster greater self-awareness, an internalized moral perspective, balanced processing of information, and relational transparency on the part of leaders working with followers, fostering positive self-development (Walumbwa et al., 2008; Gardner, 2011). Another important variable considered in our model, innovative behavior, can be defined as employee's intentional introduction or application of new ideas, products, processes, and procedures to his or her work role, work unit, or organization (West \& Farr, 1989, 1990b). Generally speaking, positive leadership always leads to employee's positive behavior. (Youssef \& Luthans, 2013), authentic leadership is a kind of positive leadership that caring about collective benefits and interest, this would enable team members to engage in related activities for the benefit of the collective (Avolio et al., 2004). Furthermore, innovative behavior has been described as the foundation of team development and competition (Suliman, 2013). Thus, under the influence of authentic leadership, employees tend to do more try in innovative behavior.

Specifically speaking, Self-awareness is the degree to which the leader demonstrates an understanding of how (s)he derives and makes sense of the world and is aware of his or her strengths, limitations, how others see him or her, and how (s)he impacts others (Kernis, 2003; Walumbwa et al., 2008). In other words, innovative behavior is also the process making use of one's advantages and avoiding one's weaknesses to put up with develop new ideas and products, in addition, balanced processing is the degree to which the leader shows that their objectively analyzes the relevant data before coming to a decision and solicits views that challenge deeply held positions (Gardner et al., 2005; Walumbwa et al., 2008), this is very benefit to creative thinking, And there is no doubt that innovative behavior is a process to collect information and make use of information resources to achieve goal and make novel decision (Kim \& Lee, 2013). Employees view the leader as a credible source of input and feedback (Walumbwa et al., 2008). Employees tend to find different pathways for solving problems and taking risks (Avolio et al., 2004). Besides, internalized moral perspective, it refers to the degree to which the leader sets a high standard for moral and ethical conduct, guides actions by internal moral standards and value, and this is also would encourage employees to expresses decision making and behaviors (Avolio \& Gardner, 2005; Gardner et al., 2005; Walumbwa et al., 2008). Last but not least, relational transparency, is the degree to which the leader presents his/her authentic self to others, openly shares information, and expresses his/her true thoughts and feelings, reinforcing a level of openness with others that provides them with an opportunity to be forthcoming with their ideas, challenges, and opinions. To a certain extent, the generation of innovative behavior is often inseparable from the knowledge gathering and information sharing (Kim \& Lee, 2013). By providing mission information and expertise, employees collaborate with others to solve problems, develop new ideas and products, implement service or procedures (Cummings, 2004). Considering Above all, we therefore make the following assumptions: 
Hypothesis 1: There will be a significantly positive correlation between authentic leadership and innovative behavior.

\subsection{The Mediating Role of Employee Well-Being}

Scholars found that employee well-being involves three basic aspects: life, work, and psychological needs in both work and life aspects. Scholars propose that employee well-being involves not only employee's perceptions and feelings about their work and life satisfaction but also their psychological experience and the level of satisfaction exhibited in both their work and personal lives. Therefore, the employee well-being concept is three dimensional and encompasses life well being, workplace well being, and psychology well being (Zheng et al., 2015). Although there are many studies that have proven the link between authentic leadership and employee well-being, and the link between employee well-being and innovative behavior, there is little research take employee well-being as an intermediary variable to explain the specific relationship between authentic leadership and innovative behavior. Therefore, we will explore the specific relationship between them.

There are various evidences shows that authentic leadership and well being are closed related (llies et al., 2005; Rahimnia et al., 2015; Farida et al., 2009). Firstly, they both reflect positive psychological resources within individual from their definition, we know that authentic leadership is a process that draws from leader's positive psychological capacities (Gardner, 2011), and employee well-being also reflects person's positive emotion and positive cognition (Zheng et al., 2015). In addition, other positive form of leadership, for example, transformational leadership, ethical leadership, has been confirmed that it is positively related to well-being (sharifirad et al., 2013; Tu \& Lu, 2013). Thus, authentic leadership might also have a certain connection with employee well-being. Secondly, four dimensions of authentic leadership can be also roughly mapped onto three aspects of employee well being. More specifically, authentic leaders are known as those who are deeply aware of their values and beliefs, self-confidant, genuine, reliable and trustworthy (Avolio \& Gardner, 2005; Gardner et al., 2005), and authentic relational orientation of leader would lead to positive interaction between authentic leader and employees, employee might experience more psychological pleasure, then enhance employees' psychological well-being. Besides, self-awareness enable employee to know which kind of life they like, and they also tend to satisfy with their life, employees can do better in work family balance, and which might help to enhance employee's life well being. What's more, unbiased processing would enhance one's personal growth through self-development (Ilies et al., 2005), and it would further enhance employee's workplace well being. Furthermore, authentic behaviors and actions would make employee dare to do more try to in his occupation and they might achieve their career goal. Therefore, we have reason to think that authentic leadership is positively related to employee well-being.

There is also some empirical research support that employee well-being is po- 
sitively related to innovative behavior (Sharifirad, 2013). Generally speaking, employee who owns positive psychological resources or happy feelings would usually lead to constructive behavior (Nordin et al., 2012). Specifically speaking, life well-being mainly states that individual satisfied with their life, and they think they are close to their dream in most aspects of their life, and life satisfaction (Zheng et al., 2015), it would help to facilitate employee's work family balance and would help to engaged more innovative behavior. In addition, employees who own work place well-being are more satisfied with their job and they would find ways to enrich their work (Zheng et al., 2015), and psychology well-being would help to create an open atmosphere, workplace well-being enable employee to do more try to in his work and they are willing to engaged innovative behavior (Zheng et al., 2015).

To sum up, we hypothesize:

Hypothesis 2: employee well-being mediates the relationship between authentic relationship and innovative behavior.

\subsection{The Moderator Role of Organizational Innovative Climate}

Innovation is not happening in a vacuum, and innovation is not only influenced by individual factors, but also by contextual factors (Woodman et al., 1993). According to the existing research, empirical studies show that contextual factor is also important for innovative behavior (Shalley et al., 2004; Hammond et al., 2011). In this study, we have considered the individual factors of employee well-being, however, contextual factor hasn't considered in our model. According to the literature, organizational innovative climate, one important contextual factor, which has been confirmed that it is positively related to innovative behavior (Yu et al., 2013; Ren \& Zhang, 2015). Specifically speaking, organizational innovative climate includes four factors, they are vision, participative safety, task orientation, and support for innovation. When the team has a higher level of organizational innovative climate, happy employee would feel the support and encouragement from the organization, and employee's ability to innovate will be maximized (Amabile et al., 1996; Oldham \& Cummings, 1996). On the contrary, When the team has a lower level of Organizational innovative climate, employees will show low motivation to innovative behavior, although the staff feel happy, because of employees lack of appropriate support of the organization, the employee's happiness wouldn't be transformed into effective innovative behavior, and thus, the relationship strength between employee well-being and innovative behavior would be weakened. Based on the above view, we hypothesize:

Hypothesis 3: Organizational innovative climate moderate the relationship between employee well-being and innovative behavior.

\section{The Framework for Research}

Based on the analysis of previous literatures, we put forward the researching framework among authentic leadership, employee well-being, organizational 


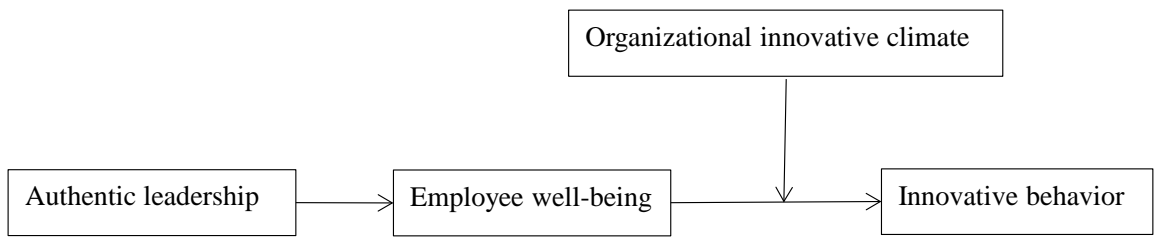

Figure 1. Research model among authentic leadership, employee well-being, organizational innovative climate and innovative behavior.

innovative behavior and innovative behavior. As we show in Figure 1, we put forward three hypothesizes in this research, they are 1) There will be a significantly positive correlation between authentic leadership and innovative behavior. 2) Employee well-being mediated the relationship between authentic relationship and innovative behavior. 3) Organizational innovative climate moderates the relationship between employee well-being and innovative behavior.

\section{Conclusion}

This research model aims to explore the relationship between authentic leadership and innovative behavior through literature research method; we also illustrate the intermediary mechanism by considering employee well-being. And organizational innovative climate might moderate the relationship between employee well-being and innovative behavior. We think that these results would be helpful to the business development. Companies could better encourage leaders to implement authentic leadership in order to enhance employee well-being and enable employees to engage in more innovative behavior. What's more, support from the organization is also essential; companies should create an atmosphere to support employees to engage in innovative behavior. However, this research also has its limitation; for example, this model hasn't been tested by empirical studies. Thus, future research could try to do some related empirical studies, and explore other potential mechanisms in authentic leadership.

\section{References}

Avolio, B. J., \& Gardner, W. L. (2005). Authentic Leadership Development: Getting to the Root of Positive Forms of Leadership. Leadership Quarterly, 16, 315-338. https://doi.org/10.1016/j.leaqua.2005.03.001

Avolio, B. J., Gardner, W. L., Walumbwa, F. O., Luthans, F., \& May, D. R. (2004). Unlocking the Mask: A Look at the Process by Which Authentic Leaders Impact Follower Attitudes and Behaviors. Leadership Quarterly, 15, 801-823. https://doi.org/10.1016/j.leaqua.2004.09.003

Crossan, M. M., \& Apaydin, M. (2010). A Multi-Dimensional Framework of Organizational Innovation: A Systematic Review of the Literature. Journal of Management Studies, 47, 1154-1191. https://doi.org/10.1111/j.1467-6486.2009.00880.x

Cummings, J. N. (2004). Work Groups, Structural Diversity, and Knowledge Sharing in a Global Organization. Management Science, 50, 352-364. https://doi.org/10.1287/mnsc.1030.0134

Fan, H. L., Chang, P. F., Albanese, D., Wu, J. J., Yu, M. J., \& Chuang, H. J. (2016). Multi- 
level Influences of Transactive Memory Systems on Individual Innovative Behavior and Team Innovation. Thinking Skills \& Creativity, 19, 49-59.

https://doi.org/10.1016/j.tsc.2015.11.001

Farida, R., \& Ingrid, D. (2009). Organizational Creativity and Innovation in Relation to Psychological Well-Being and Organizational Factors. Creativity Research Journal, 21, 191-198. https://doi.org/10.1080/10400410902855283

Fredrickson, B. L. (1998). What Good Are Positive Emotions? Review of General Psychology, 2, 300-319. https://doi.org/10.1037/1089-2680.2.3.300

Gardner, W. L., Avolio, B. J., Luthans, F., May, D. R., \& Walumbwa, F. (2005). “Can You See the Real Me?" a Self-Based Model of Authentic Leader and Follower Development. Leadership Quarterly, 16, 343-372. https://doi.org/10.1016/j.leaqua.2005.03.003

Gardner, W. L., Cogliser, C. C., Davis, K. M., \& Dickens, M. P. (2011). Authentic Leadership: A Review of the Literature and Research Agenda. Leadership Quarterly, 22, 1120-1145. https://doi.org/10.1016/j.leaqua.2011.09.007

Garud, R., Tuertscher, P., \& Van de Ven, A. H. (2013). Perspectives on Innovation Processes. Academy of Management Annals, 7, 775-819.

https://doi.org/10.1080/19416520.2013.791066

Hammond, M. M., Neff, N. L., Farr, J. L., Schwall, A. R., \& Zhao, X. (2011). Predictors of Individual-Level Innovation at Work: A Meta-Analysis. Psychology of Aesthetics Creativity \& the Arts, 5, 90-105. https://doi.org/10.1037/a0018556

Kernis, M. H. (2003). Toward a Conceptualization of Optimal Self-Esteem. Psychological Inquiry, 14, 1-26. https://doi.org/10.1207/S15327965PLI1401_01

Kim, T. T., \& Lee, G. (2013). Hospitality Employee Knowledge-Sharing Behaviors in the Relationship between Goal Orientations and Service Innovative Behavior. International Journal of Hospitality Management, 34, 324-337.

https://doi.org/10.1016/j.ijhm.2013.04.009

llies, R., Morgeson, F. P., \& Nahrgang, J. D. (2005). Authentic Leadership and Eudaemonic Well-Being: Understanding Leader-Follower Outcomes. Leadership Quarterly, 16, 373-394. https://doi.org/10.1016/j.leaqua.2005.03.002

Meyer, R. D., Dalal, R. S., \& Hermida, R. (2010). A Review and Synthesis of Situational Strength in the Organizational Sciences. Journal of Management, 36, 121-140. https://doi.org/10.1177/0149206309349309

Oldham, G. R., \& Cummings, A. (1996). Employee Creativity: Personal and Contextual Factors at Work. Academy of Management Journal, 39, 607-634. https://doi.org/10.2307/256657

Özarall1, N. (2015). Linking Empowering Leader to Creativity: The Moderating Role of Psychological (Felt) Empowerment. Procedia-Social and Behavioral Sciences, 181, 366-376. https://doi.org/10.1016/j.sbspro.2015.04.899

Özlem, A. A., Aslan, T., \& Alpkan, L. (2016). Review of Practical Implications in Authentic Leadership Studies. Procedia-Social and Behavioral Sciences, 229, 246-252. https://doi.org/10.1016/j.sbspro.2016.07.135

Rahimnia, F., \& Sharifirad, M. S. (2015). Authentic Leadership and Employee Well-Being: the Mediating Role of Attachment Insecurity. Journal of Business Ethics, 132, 363-377. https://doi.org/10.1007/s10551-014-2318-1

Rego, A., Sousa, F., Marques, C., \& Cunha, M. P. E. (2014). Hope and Positive Affect Mediating the Authentic Leadership and Creativity Relationship. Journal of Business Research, 67, 200-210. https://doi.org/10.1016/j.jbusres.2012.10.003

Ren, F. F., \& Zhang, J. H. (2015). Job Stressors, Organizational Innovation Climate, and 
Employees' Innovative Behavior. Creativity Research Journal, 27, 16-23. https://doi.org/10.1080/10400419.2015.992659

Ryan, R. M., \& Deci, E. L. (2000). Self-Determination Theory and the Facilitation of Intrinsic Motivation, Social Development, and Well-Being. American Psychologist, 55, 68-78. https://doi.org/10.1037/0003-066X.55.1.68

Shalley, C. E., Zhou, J., \& Oldham, G. R. (2004). The Effects of Personal and Contextual Characteristics on Creativity: Where Should We Go from Here? Journal of Management, 30, 933-958. https://doi.org/10.1016/j.jm.2004.06.007

Sharifirad, M. S. (2013). Transformational Leadership, Innovative Work Behavior, and Employee Well-Being. Global Business Perspectives, 1, 198-225. https://doi.org/10.1007/s40196-013-0019-2

Slimane, M. (2015). Relationship between Innovation and Leadership .Procedia-Social and Behavioral Sciences, 181, 218-227. https://doi.org/10.1016/j.sbspro.2015.04.883

Suliman, A. (2013). Organizational Justice and Innovation in the Workplace: The Case of the UAE. Journal of Management Development, 32, 945-959. https://doi.org/10.1108/JMD-03-2012-0037

Tewari, R. (2011). Individual Innovation and Organizational Success: Theoretical Perspective. Review of Management, 1.

Tu, Y. D., \& Lu, X. X. (2013). Erratum to: How Ethical Leadership Influence Employees' Innovative Work Behavior: A Perspective of Intrinsic Motivation. Journal of Business Ethics, 116, 457-457. https://doi.org/10.1007/s10551-012-1509-X

Walumbwa, F. O., Avolio, B. J., Gardner, W. L., Wernsing, T. S., \& Peterson, S. J. (2008). Authentic Leadership: Development and Validation of a Theory-Based Measure. Journal of Management, 34, 89-126. https://doi.org/10.1177/0149206307308913

Wegner, D. M. (1987). Transactive Memory: A Contemporary Analysis of the Group Mind. Theories of Group Behavior. New York: Springer. https://doi.org/10.1007/978-1-4612-4634-3_9

West, M. A., \& Farr, J. L. (1989). Innovation at Work: Psycho Logical Perspectives. Social Behavior, 4, 15-30.

West, M. A., \& Farr, J. L. (1990). Innovation and Creativity at Work: Psychological and Organizational Strategies. Health Policy, 45, 175-186.

Woodman, R. W., Sawyer, J. E., \& Griffin, R. W. (1993) Toward a Theory of Organizational Creativity. Academy of Management Review, 18, 293-321.

Youssef, C. M., \& Luthans, F. (2013). Positive Leadership: Meaning and Application across Cultures. Organizational Dynamics, 42, 198-208.

https://doi.org/10.1016/j.orgdyn.2013.06.005

Yu, C., Yu, T. F., \& Yu, C. C. (2013). Knowledge Sharing, Organizational Climate, and Innovative Behavior: A Cross-Level Analysis of Effects. Social Behavior \& Personality An International Journal, 41, 143-156(14). https://doi.org/10.2224/sbp.2013.41.1.143

Yuan, F., \& Woodman, R. W. (2010). Innovative Behavior in the Workplace: The Role of Performance and Image Outcome Expectations. Academy of Management Journal, 53, 323-342. https://doi.org/10.5465/AMJ.2010.49388995

Zhang, Z., Wang, M., \& Shi, J. Q. (2012). Leader-Follower Congruence in Proactive Personality and Work Outcomes: The Mediating Role of Leader-Member Exchange. Academic of Management Journal, 55, 111-130. http://dx.doi.org/10.5465/amj.2009.0865

Zheng, X., Zhu, W., Zhao, H., \& Zhang, C. (2015). Employee Well-Being in Organizations: Theoretical Model, Scale Development, and Cross-Cultural Validation. Journal of Organizational Behavior, 36, 621-644. https://doi.org/10.1002/job.1990 
Submit or recommend next manuscript to SCIRP and we will provide best service for you:

Accepting pre-submission inquiries through Email, Facebook, LinkedIn, Twitter, etc. A wide selection of journals (inclusive of 9 subjects, more than 200 journals)

Providing 24-hour high-quality service

User-friendly online submission system

Fair and swift peer-review system

Efficient typesetting and proofreading procedure

Display of the result of downloads and visits, as well as the number of cited articles Maximum dissemination of your research work

Submit your manuscript at: http://papersubmission.scirp.org/

Or contact ojl@scirp.org 